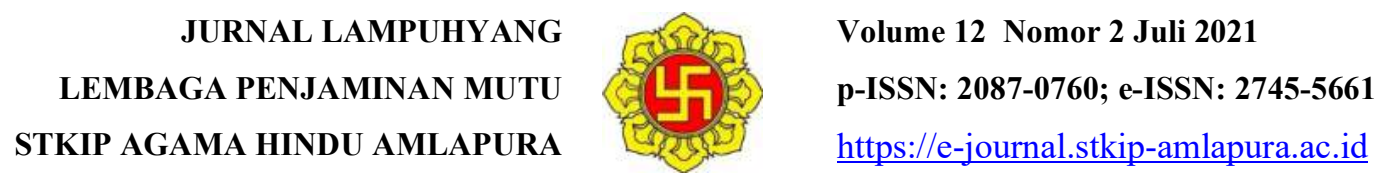

\title{
Penerapan Pendekatan Saintifik dengan Model Pembelajaran Kooperatif Tipe Student Team-Ahievment Divisions (STAD) untuk Meningkatkan Prestasi Belajar Matematika
}

\author{
Ni Ketut Putri \\ SD Negeri 2 Subagan \\ niketutputri3@gmail.com
}

\begin{tabular}{|l|l|l}
\hline Direvisi: 22 Juni 2021 & Diterima: 28 Juni 2021 & Diterbitkan: 1 Juli 2021 \\
\hline
\end{tabular}

\begin{abstract}
Abstrak: Penelitian ini dilatarbelakangi oleh rendahnya prestasi belajr matematika siswa kelas IV yang dicirikan dengan banyaknya siswa yang nilainya belum mencapai KKM yang telah ditentukan sebesar 60. Berdasarkan permasalahan tersebut, adapun tujuan penelitian ini adalah mendeskripsikan prestasi belajar siswa dengan penggunaan pendekatan saintifik dengan model pembelajaran kooperatif tipe pembelajaran STAD. Penelitian ini merupakan penilitian PTK yang dilakukan sebanyak dua siklus. Setiap sikulus terdiri atas perencanaan, pelaksanaan, observasi dan repleksi. Subjek penelitian ini adalah siswa kela IV Sekolah Dasar Negeri 2 Subagan tahun pelajaran 2018/2019 sebanyak 10 siswa. Data prestasi belajar dikumpulkan dengan tes yang berbentu objektif. Hasil analisis data menunjukkan bahwa pendekatan sainstifik dengan model pembelajaran kooperatif tipe STAD dapat meningkatkan prestasi belajar matematika siswa. Berdasarkakan hasil tersebut maka dalam penelitian ini dapat diajukan beberapa saran sebagai berikut: 1) kepada guru agar dalam proses pembelajaran menggunakan pendekatan saintifik dengan metode STAD 2) Bagi yang berminat untuk mengadakan penelitian yang lebih lanjut agar memperhatikan kendala-kendala yang peneliti alami sebagai bahan pertimbangan untuk penyempurnaan penelitian yang dilaksanakan.
\end{abstract}

Kata kunci : Prestasi Belajar, Matematika, Saintifik, STAD

\begin{abstract}
This research is motivated by the low mathematics learning achievement of fourth grade students which is characterized by the number of students whose scores have not reached the predetermined KKM of 60. Based on these problems, the purpose of this study is to describe student learning achievement by using a scientific approach with a cooperative learning model. STAD learning type. This research is a CAR research conducted in two cycles. Each cycle consists of planning, implementation, observation and reflection. The subjects of this study were the fourth grade students of State Elementary School 2 Subagan in the 2018/2019 academic year as many as 10 students. Learning achievement data was collected with an objective test. The results of data analysis
\end{abstract}


show that the scientific approach with the STAD type cooperative learning model can improve students' mathematics learning achievement. Based on these results, in this study some suggestions can be made as follows: 1) to teachers so that in the learning process using a scientific approach with the STAD method 2) For those who are interested in conducting further research to pay attention to the constraints experienced by researchers as consideration for the completion of the research carried out.

Keywords: Learning Achievement, Mathematics, Scientific, STAD

\section{PENDAHULUAN}

\subsection{Latar Belakang Masalah}

Mengembangkan peserta

didik seutuhnya mencakup aspek jamani dan rohani sarat dengan kendala. Sebagai contoh, membentuk peserta didik yang memiliki ilmu matematika yang dicirikan melaui sikap, pengetahuan, dan keterampilan (aspek kognitif, apektif, dan psikomotor) tidaklah mudah. Terlebih pada siswa di kelas awal Sekolah Dasar. Padahal pendidikan dikelas awal merupakan pondasi untuk membentuk pengetahuan selanjutnya. Apa bila pondasi pengetahun tidak bagus ditanamkan diawal akan sangat sulit untuk memperbaiki selanjutnya. Begitu pula halnya dengan siswa di Sekolah Dasar Negeri 2 Subagan.

Bagi sebagian besar siswa Sekolah Dasar kelas IV termasuk di Sekolah Dasar Negeri 2 Subagan, pelajaran matematika masih menjadi mata pelajaran yang kurang diminati hal ini karena matematika adalah mata pelajaran yang dianggap sulit. Kurangnya minat siswa terhadap pelajaran matematika dapat dilihat dari kurang aktifnya siswa dalam mengikuti pelajaran matematika (berdasarkan hasil pengamatan terbatas). Permasalahan lain yang terjadi di kelas IV Sekolah Dasar Negeri 2 Subagan selain minat belajar yang kurang di antaranya: 1) metode yang digunakan kurang mampu melibatkan siswa dalam proses pembelajaran sehingga siswa kurang terangsang untuk belajar, 2) perhatian siswa belum pokus ketika mengikuti pembelajaran, 3) pasilitas buku pembelajaran yang masih minim. Dampak nyata yang dapat dilihat dari permasalahan yang dialami siswa dalam belajar matematika adalah prestasi belajar 
matematika siswa cenderung berada

di bawah standar ketuntasan belajar minimal yang ditetapkan sekolah. Secara empiris untuk semester ganjil tahun pelajaran 2018/2019 prestasi belajar matematika siswa kelas IV secara rata-rata selalu berada di bawah KKM yang telah ditentukan sebesar 60. Rerata prestasi belajar siswa keas IV bila dilihat dari hasil ulangan free test sebesar 55,00 Ketuntasan belajar sebesar 50 persen. Padahal harapannya prestasi belajar siswa secara klasikal minimal 60 sesuai dengan KKM dan ketuntasan klasikal mencapai 75 persen keatas.

Permasalahan tersebut tentu mebutuhkan penanganan dengan melakukan proses pembelajaran yang lebih baik sesusi dengan tuntutan kurikulum. Proses pembelajaran akan dapat berjalan secara efektif bila pendekatan yang digunakan telah dikenal oleh siswa dengan metode pembelajaranya menggunakan metode yang berpusat pada siswa sesuai dengan perkembangan kekinian. Namun kenyataannya dalam proses pebelajaran dikelas IV sekolah dasar Negeri 2 Subagan belum bisa diterapkan suatu metode pembelajaran yang 100 persen berpusat pada siswa. Karena diketahui bersama siswa kelas IV masih membutuhkan bimbingan. Sehingga dibutuhkan suatu metode yang mampu menjembatani permasalahan tersebut. Sejumlah hasil penelitian yang dilakukan untuk kelas awal yang mampu memperbaiki kualitas pembelajaran adalah metode kelompok kecil tipe Student Team-Achievement Divisions yang selanjutnya dalam penelitian ini penulisannya disingkat menjadi STAD. Menurut penemunya metode STAD merupakan salah satu metode pembelajaran kelompok kecil yang paling sederhana dan cocok diterapkan disemua kelas. Berpijak darai hasil penelitian dan pandangan tentang metode STAD tersebut berarti metode ini bisa digunakan untuk memperbaiki kualitas pembelajaran di kelas IV Sekolah Dasar Negeri 2 Subagan. Bila dicermati sintaks dari metode ini pada bagain awal seperti pembelajaran ceramah. Dimana guru memiliki peran menyampikan informasi terkait materi 
pembelajaran. Selanjutnya baru ada kerja kelompok yang melibatkan anggota tem secara aktif. Diakhir pembelajaran diberikan penghargaan kepada kelompok yang terbaik. Bila dicermati langkah pembelajaran ini sangat cocok digunakan untuk menangani permaslaha yang terjadi di kelas IV Sekolah Dasar Negeri 2 Subagan. Model STAD memiliki sejumlah keunggulan bila dibandingkan dengan model yang lain di antaranya: 1) model ini merupakan model pembelajaran kooperatif yang paling sederhana. Sehingga peneliti sebagai guru yang pemula melakukan model pembelajaran kooperatif akan tidak mengalami banyak kendala. 2) model pembelajaran ini walaupun sederhana tetap menuntut adanya kerjasama tim. Sehingga dapat minigkatkan aktivitas siswa dalam pembelajaran. 3) model pembelajaran ini dalam salah satu fasenya mencatumkan adanya penghargaan dengan demikian akan dapat merangsang siswa untuk aktivitas dalam pembelajaran. 4) secara fsikologis model ini cocok diterapkan pada kelas pemula khusnya pada tingkat sekolah dasar. Karena tindak terlalu menuntut pemikiran terlau kompleks. Oleh karenanya penelitian ini sangat penting untuk dilaksanakan. Penerapan model STAD dalam pembelajaran sesuai dengan penerapan kurikulum 2013. Pendekatan yang digunakan adalah pendekatan Saintifik yang terdiri dari kegiatan 5M. Dalam model pembelajaran STAD selajan dengan pendekatan yang digunakan. Berdasarkan permasalahan yang telah diuraikan, untuk memperbaiki kualitas pembelajaran yang terjadi di kelas IV Sekolah Dasar Negeri 2 Subagan peneliti tertarik melakukan penelitian dengan judul "Penerapan Pendekatan Saintifik dengan Model Pembelajaran Student TeamAchievement Divisions (STAD) untuk meningkatkan prestasi belajar Matematika Siswa Kelas IV Sekolah Dasar Negeri 2 Subagan Tahun pelajaran 2018/2019”.

\subsection{Rumusan Masalah}

Berdasarkan latar belakang di
atas, rumusan masalah dalam
penelitian ini sebagai berikut.


Apakah dengan Penerapan

Pendekatan Saintifik dengan model pembelajaran STAD dapat meningkatkan prestasi belajar Matematika siswa kelas IV di Sekolah Dasar Negeri 2 Subagan tahun pelajaran 2018/2019?

\subsection{Tujuan Penelitian}

Berdasarkan permasalahan tersebut, tujuan penelitian ini adalah untuk meningkatkan prestasi belajar Matematika di kelas IV pada Sekolah Dasar Negeri 2 Subagan tahun pelajaran 2018/2019.

\subsection{Manfaat Penelitian}

Dalam penelitian ini dapat dibedakan menjadi dua, yakni manfaat teoretis dan manfaat praktis. Manfaat teoretis adalah pengembangan ilmu pengetahuan secara umum untuk menambah khasanah ilmu pengetahuan dalam bidang agama hindu dan metode pembelajaranya. Manfaat prasktis adalah pengembangan ilmu pengetahuan yang bisa bermamfaat secara langsung bagi pihak-pihak berikut. Bagi siswa, melalui penerapan pendekatan Saintifik dengan Model pembelajaran STAD untuk meningkatkan hasil prestasi belajar siswa serta mengarahkan siswa berpikir kritis dan analitis terhadap masalah yang dihadapinya. Bagi guru, maksudnya secara langsung guru mampu meningkatkan ke profesionalannya dalam memberikan pelajaran kepada siswa dan merancang pembelajaran. Bagi sekolah, maksudnya pengembangan ilmu pengetahuan bermanfaat untuk meningkatkan mutu pendidikan di sekolah. Bagi eneliti lain, maksudnya secara langsung sebagai bahan referensi ketika menulis penelitian yang sama.

\section{TINJAUAN PUSTAKA}

\subsection{Pendekatan Saintifik}

$\begin{array}{llr}\text { Pendekatan } & \text { saintifik } & \text { dalam } \\ \text { pembelajaran } & \text { adalah } & \text { proses } \\ \text { pembelajaran } & \text { yang } & \text { dirancang }\end{array}$
sedemikian rupa agar peserta didik secara aktif mengkonstruk konsep, prosedur, hukum atau prinsip, melalui tahapan-tahapan mengamati, merumuskan masalah, mengajukan atau merumuskan hipotesis, mengumpulkan data, menganalisis data, menarik kesimpulan, dan 
mengkomunikasikan. Proses pembelajaran pendekatan saintifik mengacu pada pendekatan langkah berpikir saintifik, mengandung 5 (lima) langkah yang tidak selalu harus berurut dan seluruhnya ada dalam satu kali pertemuan pembelajaran, yaitu sebagai berikut.

1) Mengamati, yaitu kegiatan siswa mengidentifikasi melalui indera penglihat (membaca, menyimak), pembau, pendengar, pengecap dan peraba pada waktu mengamati suatu objek dengan ataupun tanpa alat bantu. Alternatif kegiatan mengamati antara lain observasi lingkungan, mengamati gambar, video, tabel dan grafik data, menganalisis peta, membaca berbagai informasi yang tersedia di media masa dan internet maupun sumber lain. Bentuk hasil belajar dari kegiatan mengamati adalah siswa dapat mengidentifikasi masalah.

2) Menanya, yaitu kegiatan siswa mengungkapkan apa yang ingin diketahuinya baik yang berkenaan dengan suatu objek, peristiwa, suatu proses tertentu.
Dalam kegiatan menanya, siswa membuat pertanyaan secara individu atau kelompok tentang apa yang belum diketahuinya. Siswa dapat mengajukan pertanyaan kepada guru, narasumber, siswa lainnya dan atau kepada diri sendiri dengan bimbingan guru hingga siswa dapat mandiri dan menjadi kebiasaan. Pertanyaan dapat diajukan secara lisan dan tulisan serta harus dapat membangkitkan motivasi siswa untuk tetap aktif dan gembira. Bentuknya dapat berupa kalimat pertanyaan dan kalimat hipotesis. Hasil belajar dari kegiatan menanya adalah siswa dapat merumuskan masalah dan merumuskan hipotesis.

3) Mengumpulkan data, yaitu kegiatan siswa mencari informasi sebagai bahan untuk dianalisis dan disimpulkan. Kegiatan mengumpulkan data dapat dilakukan dengan cara membaca buku, mengumpulkan data sekunder, observasi lapangan, uji coba (eksperimen), wawancara, menyebarkan kuesioner, dan 
lain-lain. Hasil belajar dari kegiatan mengumpulkan data adalah siswa dapat menguji hipotesis.

4) Mengasosiasi, yaitu kegiatan siswa mengolah data dalam bentuk serangkaian aktivitas fisik dan pikiran dengan bantuan peralatan tertentu. Bentuk kegiatan mengolah data antara lain melakukan klasifikasi, pengurutan (sorting), menghitung, membagi, dan menyusun data dalam bentuk yang lebih informatif, serta menentukan sumber data sehingga lebih bermakna. Kegiatan siswa dalam mengolah data misalnya membuat tabel, grafik, bagan, peta konsep, menghitung, dan pemodelan. Selanjutnya siswa menganalisis data untuk membandingkan ataupun menentukan hubungan antara data yang telah diolahnya dengan teori yang ada sehingga dapat ditarik simpulan dan atau ditemukannya prinsip dan konsep penting yang bermakna dalam menambah skema kognitif, meluaskan pengalaman, dan wawasan pengetahuannya. Hasil belajar dari kegiatan menalar/mengasosiasi adalah siswa dapat menyimpulkan hasil kajian dari hipotesis.

5) Mengomunikasikan, yaitu kegiatan siswa mendeskripsikan dan menyampaikan hasil temuannya dari kegiatan mengamati, menanya, mengumpulkan dan mengolah data, serta mengasosiasi yang ditujukan kepada orang lain baik secara lisan maupun tulisan dalam bentuk diagram, bagan, gambar, dan sejenisnya dengan bantuan perangkat teknologi sederhana dan atau teknologi informasi dan komunikasi. Hasil belajar dari kegiatan mengomunikasikan adalah siswa dapat memformulasikan dan mempertanggungjawabkan pembuktian hipotesis.

\subsection{Karakteristik Pembelajaran}

\section{Kooperatif}

Ciri khas dari pembelajaran kooperatif adalah adanya pembelajaran kelompok. Savin, Abrini, dan Chembers (1996) dalam Sanjaya (2009), berpendapat bahwa 
belajar melalui kooperatif dapat dijelaskan dari berbagai perspektif, yaitu prektif motivasi, prespektif sosial,perpektif perkembangan kognitif,dan perspektif elaboras kognitif. Karakteristik pembelajaran kooperatif adalah, sebai berikut: 1) pembelajaran secara tim, 2) didasarkan pada manajemen kooperatif, 3) kemauan untuk bekerja sama, dan 4) keterampilan bekerja sama.

Berdasarkan pemaparan tersebut, dapat disimpulkan bahwa ciri khas pembalajaran kooperatif adalah pembelajaran kelompok yang mengutamakan kerjasma tim. Kemampuan bekerjasama menjadi ciri khas yang dituntut oleh model pembelajaran ini.

\subsection{Pembelajaran Kooperatif} Model STAD

STAD (Student Team-

Achievement Divisions) merupakan salah satu metode pembelajaran kooperatif yang paling sederhana, dan model yang paling baik untuk permulaan bagi guru yang baru menggunakan pendekatan kooperatif (Slavin, 2005:143). STAD terdiri atas lima komponen utama yaitu presentasi kelas, tim, kuis, skor kemajuan individual, dan rekognisi tim. Untuk lebih memudahkan memahami STAD setiap langkah disajikan dalam tabel berikut.

Tabel 01 Langkah Pembelajaran STAD

\begin{tabular}{|l|l|}
\hline Fase & \multicolumn{1}{|c|}{ Deskripsi } \\
\hline Presentasi kelas & $\begin{array}{l}\text { Pada fase ini merupakan pengajaran langsung seperti } \\
\text { yang sering dilakukan atau diskusi pembelajaran yang } \\
\text { dipimpin oleh guru. Bedanya adalah presentasi tersebut } \\
\text { harus benar benar berfokus pada unit STAD, sehingga } \\
\text { siswa akan menyadari bahwa mereka harus } \\
\text { memperhatikan secara penuh presentasi kelas, dengan } \\
\text { demikian mereka dapat mengerjakan kuis-kusi dengan } \\
\text { baik karena hasil kuis mempengaruhi skor tim mereka. }\end{array}$ \\
\hline Tim & $\begin{array}{l}\text { Tim terdiri atas empat atau lima siswa yang mewakili } \\
\text { seluruh bagian dari kelas dalam hal kinerja akademik, } \\
\text { jenis kelamin, ras dan etnisitas. Setelah guru menjelaskan } \\
\text { materi tim berkumpul untuk mengerjakan lembar materi } \\
\text { atau materi lainnya. Anggota tim melakukan pembahasan } \\
\text { bersama, membangdingkan jawaban, dan mengoreksi } \\
\text { setiap kesalahan pemahaman apabila anggota tim ada } \\
\text { yang membuat kesalahan. Tim merupakan figur yang }\end{array}$ \\
\hline
\end{tabular}




\begin{tabular}{|l|l|}
\hline Kuis & paling penting dalam STAD. \\
\hline $\begin{array}{l}\text { Skor Kemajuan } \\
\text { Individual }\end{array}$ & $\begin{array}{l}\text { Setelah sekitar satu atau dua periode guru memberikan } \\
\text { presentasi dan sekitar satu atau dua periode praktik tim, } \\
\text { para siswa akan mengerjakan kuis individual. Para siswa } \\
\text { tidak bole saling membantu dalam mengerjakan kuis. } \\
\text { Sehingga setiap siswa bertanggung jawab secara individu } \\
\text { untuk memahami materinya. }\end{array}$ \\
$\begin{array}{l}\text { memberikan kepada siswa tujuan kinerja yang akan dapat } \\
\text { dicapai apabila mereka bekerja lebih giat dan } \\
\text { memberikan kinerja yang lebih baik daripada } \\
\text { sebelumnya. Tiap skor awal, yang berikan dari rerata } \\
\text { kinerja siswa tersebut sebelumnya dalam mengerjakan } \\
\text { kuis yang sama. Siswa akan mengumpulkan poin untuk } \\
\text { tim mereka berdasarkan tingkat kenaikan skor kuis } \\
\text { mereka dibandingkan dengan skor awal mereka. Sehingga } \\
\text { anggota tim dapat memberikan kontribusi poin yang } \\
\text { maksimal untuk sisem skor ini. }\end{array}$ \\
\hline Rekognisi tim & $\begin{array}{l}\text { Tim mendapatkan sertifikat atau bentuk penghargaan } \\
\text { yang lain apa bila skor rerata mereka mencapai kreteria } \\
\text { tertentu. }\end{array}$ \\
\hline
\end{tabular}

(Sumber: Slavin, 2005)

\subsection{Prestasi Belajar}

Prestasi belajar terbentuk dari serangkaian aktivitas yang dilakukan oleh siswa sehingga bila mengkaji tentang prestasi belajar maka kurang bijak rasanya kita melupakan sejumlah aktivitas yang mendasari dari prestasi belajar tersebut. Maka sebeluum sampai pada pengertian prestasi belajar, mengingat prestasi itu didahului dengan aktivitas, maka pengertian aktivitas perlu disampaikan terlebih dahulu. Untuk memberikan pemahaman yang lebih mendalam bahwasanya prestasi belajar itu tidak serta merta ada tanpa ada yang menyebabkannya. Djamarah (2002:23) mendefinisikan prestasi belajar sebagai "hasil yang diperoleh berupa kesan-kesan yang mengakibatkan perubahan dalam diri individu sebagai hasil dari aktivitas dalam belajar". Kalau perubahan tingkah laku adalah tujuan yang mau dicapai dari aktivitas belajar, maka perubahan tingkah laku itulah salah satu indikator yang dijadikan pedoman untuk mengetahui 
kemajuan individu dalam segala hal yang diperolehnya di sekolah. Dengan kata lain prestasi belajar merupakan kemampuan-kemampuan yang dimiliki oleh siswa sebagai akibat perbuatan belajar atau setelah menerima pengalaman belajar, yang dapat dikatagorikan menjadi tiga ranah, yakni ranah kognitif, afektif, dan psikomotor.

\subsection{Hipotesis Tindakan}

Berdasarkan kajian teori di atas maka dapat dibuat jawaban sementara dari permaslahan yang diajukan sebagai berikut. Jika pendekatan Saintifik dengan dengan model pembelajaran kooperatif STAD diterapkan pada siswa kelas IV SD Negeri 2 Subagan dengan baik maka dapat meningkatkan prestasi belajar matematika pada tahun pelajaran 2018/2019.

\section{METODE PENELITIAN}

Penelitian ini menggunakan rancangan Penelitian Tindakan Kelas (PTK). Penelitian Tindakan Kelas (PTK) bertujuan untuk memperbaiki kegiatan pembelajaran agar dapat menciptakan prestasi belajar yang optimal. Penelitian dilakukan secara sistematis reflektif terhadap aksi-aksi atau tindakan yang dilakukan oleh peneliti. Penelitian dilakukan mulai dari perencanan, pelaksanaan, pengamatan dan penilaian yang bertujuan untuk memperbaiki kondisi pembelajaran dan meningkatkan kualitas hasil pembelajaran. Metode tes digunakan untuk mengumpulkan data tentang prestasi belajar siswa kelas IV Sekolah Dasar Negeri 2 Subagan dalam pembelajaran Matematika. Tes yang digunakan adalah tes objektif berbentuk pilihan ganda, yang selanjutnya data diolah dengan statistik sederhana. Penelitian ini dikatakan berhasil bila rerata prestasi belajar matematika Siswa kelas IV SD Negeri 2 Subagan mencapai 60 dan ketuntasan siswa mencapai $75 \%$.

\section{HASIL DAN PEMBAHASAN}

Berikut disajikan ringkasan prestasi belajar siswa pra siklus, siklus I dan Siklus II. 
Tabel 02 Ringkasan Hasil Penelitian Prasiklus, Siklus I, dan Siklus II

\begin{tabular}{|c|l|c|c|c|}
\hline \multirow{2}{*}{ No } & \multirow{2}{*}{ Nama Siswa } & \multicolumn{3}{c|}{ Nilai } \\
\cline { 3 - 5 } & & pra siklus & Siklus I & Siklus II \\
\hline 1 & Ni Kdk Maia Etrika Dewi & 65 & 70 & 85 \\
\hline 2 & Ni Luh Mudawati & 65 & 60 & 90 \\
\hline 3 & Ni Km. Amelia Trisna Putri & 45 & 75 & 80 \\
\hline 4 & I Gd. Prayoga Adi Putra & 75 & 55 & 75 \\
\hline 5 & Ni Putu Juniari & 60 & 65 & 95 \\
\hline 6 & I Km. Adi Widya Putra & 45 & 75 & 80 \\
\hline 7 & I Putu Deo Eka Putra & 60 & 55 & 75 \\
\hline 8 & I Komang Agus Putrawan & 30 & 40 & 55 \\
\hline 9 & Ni Kadek Sekartini & 65 & 55 & 65 \\
\hline 10 & Ni Pt. Maylani Kirana Putri & 40 & 65 & 80 \\
\hline \multicolumn{2}{|c|}{ Rerata } & 55 & 61.5 & 78 \\
\hline \multicolumn{2}{|c|}{ Ketuntasan Klasikal } & 60 persen & 60 persen & 90 persen \\
\hline
\end{tabular}

Berdasarkan tabel diatas atas maka dapat dibuat grafik hasil tentang perolehan prestasi belajar belajar seperti gambar berikut. matematika siswa secara individu di

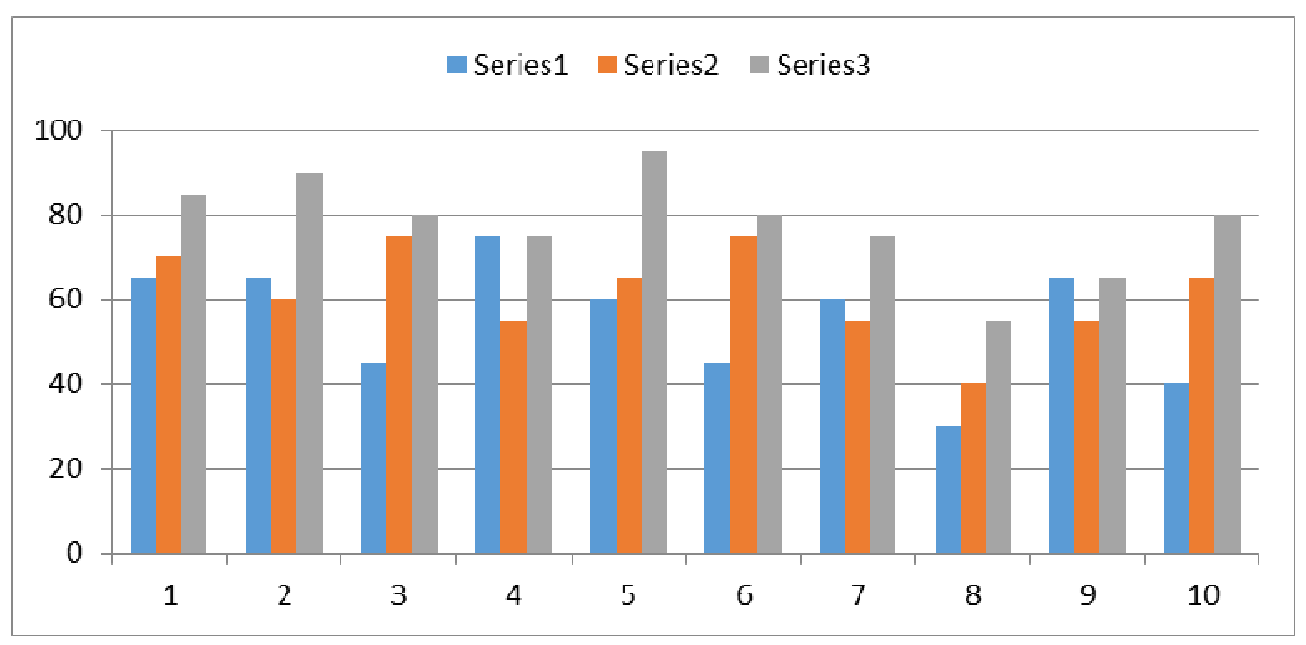

Gambar 01 Grafik Hasil Belajar secara Individu

Selanjutnya berdasarkan tabel rerata prestasi belajar secara klasikal 02 dapat dibuat grafik perbandingan seperti gambar 01 sebagai berikut. 


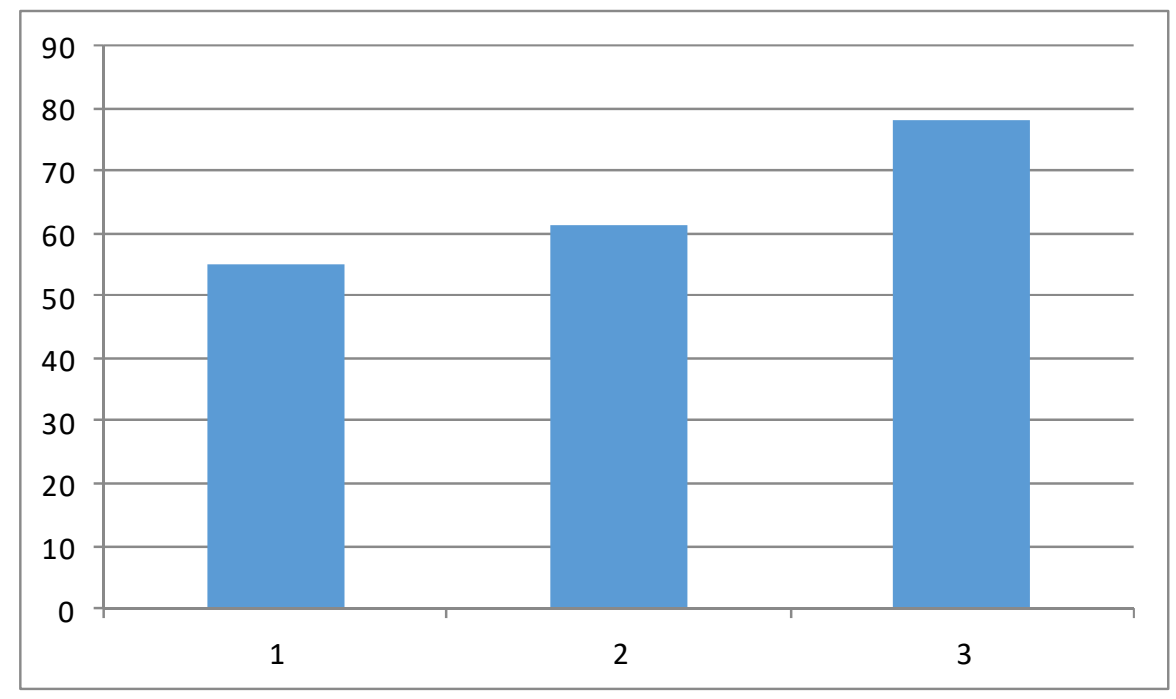

Gambar 02 Grafik Rerata Prestasi Belajar Siswa

(1) rerata sebelum penelitian, (2) rerata prestasi belajar siklus I, (3) rereta prestasi belajar siklus II

Berdasarkan peningkatan prestasi belajar sebelum penelitian, siklus I dan siklus II dapat diketahui terjadi peningkatan. Hasil refleksi pada siklus II terkait rerata prestasi belajar dan rerta ketuntasan klasikal dibandingkakan dengan indikator keberhasilan dari penelitian ini maka dapat disampaikan penelitian ini telah berhasil sesuai dengan harapan, sehingga penelitian dihentikan sampai siklus II.

Berdasarkan hasil analisis pada Siklus I menunjukkan bahwa penggunaan pendekatan Saintifik dengan model pembelajaran model STAD dapat meningkatkan prestasi belajar Matematika pada siswa kelas kelas IV Sekolah Dasar Negeri 2 Subagan tahun pelajaran 2018/2019. Rata - rata prestasi belajar pada siklus I sebesar 61,5 dan siklus II menjadi 78 sehingga dari daya serap yang diperoleh pada Siklus I sebesar $61,5 \%$ meningkat menjadi $78 \%$ pada tindakan siklus II. Berdasarkan permasalahan yang terjadi dalam proses pembelajaran pada siklus I, diadakan perbaikan supaya permasalahan dalam siklus I tidak terulang lagi pada pelaksanaan siklus II. Sehingga pada akhir siklus II ketuntasan klasikal meningkat dari 60 persen menjadi 90 persen. 
Perbaikan pada siklus II ditekankan pada pengelolaan kelas agar lebih optimal dan merangsang semua siswa untuk memberikan tanggapan terhadap pertanyaanpertanyaan yang diberikan pada saat diskusi di kelas. Hal itu dapat dilakukan dengan pemberian penguatan berupa tambahan nilai bagi siswa yang merespon dan juga membangkitkan rasa percaya diri setiap siswa agar siswa yang bersangkutan mau mengemukakan pendapat atau tanggapanya. Sementara itu, untuk mempersiapkan diri siswa dalam menghadapi tes, setiap akhir pembelajaran memberikan umpan balik berupa soal-soal yang harus dikerjakan oleh siswa di rumah dan pekerjaan siswa tersebut dibahas pada pertemuan berikutnya. Dengan pemberian umpan balik tersebut, mau tidak mau siswa akan termotivasi untuk belajar sebelum menghadapi pertemuan selanjutnya.

Berdasarkan hasil yang dicapai, dapat diketahui bahwa penelitian ini telah berhasil meningkatkan prestasi belajar matematika siswa kelas IV Sekolah
Dasar Negeri 2 Subagan. Dengan menggunakan pendekatan saintifik dengan seting model pembelajaran tipe $S T A D$ siswa lebih tertarik untuk belajar. Siswa SD Negeri 2 Subagan pada dasarnya belum pernah diajak belajar dengan menggunakan media pembelajaran Inovatif. Dengan menggunakan pendekatan Saintifik dengan seting model pembelajaran model STAD siswa lebih mudah menyerap materi pembelajaran karena setiap anak sudah punya tugas sendiri yaitu memberi dan menerima pembelajran dari temen sebayanya. Dengan model pembelajran ini maka semua siswa ikut berpartisifasi dalam proses pembelajran.

Di samping itu pemberian penghargaan diakhir siklus memberikan efek yang positif untuk meningkatkan prestasi belajar siswa. Hal ini senada dengan pendapat para ahli bahwa hasil belajar yang didapatkan oleh siswa tidak hanya dipengaruhi oleh faktor intrinsik siswa tetapi juga dipengaruhi oleh faktor ektrinsik salah satunya penghargaan pada siswa dan kelompok yang terbaik, disamping itu pemberian penghargaan dapat 
menumbuhkan kepercayaan pada diri siswa bahwa sekecil apapun hal yang dilakukan ternyata tercata dengan baik oleh guru. Dengan demikian maka siswa dalam proses pembelajaran akan lebih fokus.

\section{PENUTUP}

\subsection{Simpulan}

Berdasarkan hasil

pembahasan maka dapat disimpulkan bahwa dengan mengunakan pendekatan Saintifik dengan seting model pembelajran Student TeamAchievement Divisions (STAD) dapat meningkatkan prestasi belajar Matematika siswa kelas IV Sekolah Dasar Negeri 2 Subagan pata tahun pelajaran 2018/2019.

\subsection{Saran}

Dari hasil penelitian yang diperoleh, dapat diajukan beberapa saran yaitu sebagai berikut.

1) Bagi guru terutama guru kelas yang mengajar di SD Negeri 2 Subagan disarankan untuk menerapkan pendekatan Saintifik dengan Model Pembelajaran STAD. Bagi guru yang ingin menerapkan Penggunaan metode ini dalam pembelajaran dikelas agar mencermati dan mengantisipasi kelemahankelemahan yang ditemukan dalam penelitian ini, sehingga dapat meningkat hasil belajar siswa yang lebih optimal.

2) Bagi peneliti lain, jika berkeinginan untuk mengadakan penelitian lebih lanjut mengenai Penggunaan pendekatan saintifik dengan seting model pembelajaran STAD dalam pembelajaran matematika diharapkan mengambil materi yang lain atau materi yang lebih luas untuk menyakinkan hasil penelitian ini dan juga mengatasi kendala-kendala yang dihadapi dalam penelitian ini sehingga hasil yang diperoleh lebih maksimal.

\section{DAFTAR PUSTAKA}

Abdul. (2002). Memahami dan Menangangi Siswa Dengan Problem Dalam Belajar. Pedoman Guru, Jakarta, Proyek Peningkatan Mutu SLTP Direktorat Pendidikan Menengah Umum. Dirjen Pendidikan Dasar dan Menengah Departemen Pendidikan Nasional.। 
Anderson, Orin W. (2001). A Taxonomy for Learning, Teacning, And Assessing. New York : Longman

Arikunto, Suharsimi.

Prosedur Penelitian. Jakarta: Rineka Cipta.

Arikunto, Suharsimi. (2002). Prosedur Penelitian: Suatu Pendekatan Praktek. Jakarta: Rineka Cipta.

Badan Standar Nasional Pendidikan. (2006). Panduan Penyusunan Kurikulum Tingkat Satuan Pendidikan Jenjang Pendidikan Dasar dan Menengah. Jakarta : BSNP

Dantes, Nyoman. (2008). Kurikulum tingkat satuan pendidikan dan inovasi pembelajaran dalam kaitannya dengan pembaharuan sistem pemdidikan(disampaikan dalam lokakarya pengembangan pendekatan pembelajaran pada para guru di kabupaten buleleng5 Oktober 2008).Program Pasca Sarjana UNDIKSHA Singaraja. (tidak diterbitkan)

Dantes, Nyoman. (2009). Pengembangan Kompetensi profesional

guru(disampaikan pada seminar pendidikan di SD santo yoseph 1 denpasar Pada tanggal 25 Juli 2009). Program Pasca Sarjana UNDIKSHA Singaraja. (makalah seminar tidak diterbitkan).

Departemen Pendidikan Nasional Republik Indonesia. Undangundang Republik Indonesia Nomor 20 Tahun 2003
Tentang Sistem Pendidikan Nasional. Jakarta. 2003.

Departemen Pendidikan Nasional Republik Indonesia. Peraturan Pemerintah Republik Indonesia Nomor 19 tahun 2005 Tentang Standar Nasional Pendidikan. Jakarta. 2005.

Depdikbud. (1994). Kurikulum Pendidikan Dasar. Jakarta : Departemen Pendidikan dan Kebudayaan.

Depdiknas. (2005). Materi Pelatihan Terintegrasi, Pendidikan Kewarganegaraan. Jakarta, Direktorat Jenderal Pendidikan Dasar dan Menengah, Direktorat Pendidikan Lanjutan Pertama.

Dimyati, Moedjiono. (1994). Belajar dan Pembelajaran. Jakarta: Departemen Pendidikan dan Kebudayaan.

Direktorat Pembinaan Akademik dan Kepeserta didikan Ditjen Dikti Depdiknas. (2005). Tanya Jawab Seputar Unit Pengembangan Materi dan Proses Pembelajaran di Perguruan Tinggi. Jakarta.

Djamarah. S.B, Zain, A. (2002). Strategi Belajar Mengajar. Jakarta : PT. Rineka Cipta.

Miarso, Yusufhadi. (2004). Menyemai Benih Teknologi Pembelajaran. Jakarta: Pustekkom Diknas \& Kencana.

Purwanto. (2008). Konsep Strategi Pembelajaran. Bandung: Refika Aditama.

Pusat Kurikulum Balitbang Depdiknas. (2002). Kurikulum Berbasis 
Kompetensi. Jakarta: Depdiknas R.I.

Salim, Agus. (2006). Teori dan Padadigma penelitian Sosial Edisi Kedua. Yogyakarta:Tiara Wacana.

Sanjaya, Wina. (2009). Kurikulum dan Pembelajaran (Teori praktek pengembangan Kurikulum Tingkat Satuan Pendidikan). Jakarta:

Kencana Prenada Media Grup.

Sanjaya, Wina. (2009). Srategi Pembelajaran Berorientasi Standar Proses Pendidikan. Jakarta: Kencana Prenada Media Grup.

Slavin, (2005). Model Pembelajaran Kooperatif. Bandung : Alfabeta 